\title{
A areté heróica e a GuerRa de Tróia: o melhor dos aqueus (Aquiles, ÁjaX e Odisseu)
}

\author{
FRANCISCO MURARI PIRES \\ Departamento de História \\ Faculdade de Filosofia, Letras e Ciências Humanas \\ Universidade de São Paulo
}

\begin{abstract}
REsUM0
Fste artigo propõe uma reconsideração da (in) justiça concernente à atribuição das Earmas de Aquiles a Odisseu como o melhor dos aqueus, através da apreciação do conceito homérico de areté.
\end{abstract}

Palavras-chave: Areté; Homero; Ájax; Aquiles; Odisseu.

$1 V^{0}$

o célebre Catálogo das Naus, o aedo, Homero conclama a Musa para que lhe declare quem, dentre os chefes aqueus combatentes em Tróia, era o melhor. A Deusa então distingue dois heróis, contemplados por tal fama: Aquiles e, depois de Aquiles, Ájax. Todavia, no episódio do Juízo das Armas de Aquiles, a serem concedidas como prêmio justamente ao melhor dos aqueus, o herói agraciado é Odisseu, e não Ájax.

Kirk (1985, p. 241) em seus comentários ao texto da Ilíada, não só não esclarece sua solução, como complica ainda mais a intriga assim equacionada, pois, quando Homero destaca Ájax como o melhor dos aqueus depois de Aquiles, o crítico moderno, interpelando o poeta, ou quiçá a Deusa mesmo, interroga: por que não Diomedes?

Gregory Nagy (1986, p. 26-41) vislumbrou uma solução, ao que me parece, inversa, em seu alcance, à de Kirk. Em sua obra The Best of the Achaeans sustenta a tese de que Aquiles é o melhor dos aqueus na tradição épica corporificada para nós pela Ilíada, éOdisseu o é pela tradição da Odisséia. Já Ájax, integrado à tradição da Iliada, é apreciado como o segundo melhor dos aqueus. Solução hermenêutica no mínimo tautológica, pois informa como resposta o que são os dados mesmos postos pela pergunta.

E assim permanecemos com a questão inaugural que intrigava os antigos.

Retornemos, então, às tramas narrativas dos textos mesmos. 
Os eólios, estabelecidos na Tróade em tempos posteriores à ruína da cidadela heróica, contavam a seguinte história, registrada por Pausânias (Descrição da Grécia, I.35.4): quando Odisseu, regressando da Guerra Troiana, naufragou ao largo daquelas paragens, as armas de Aquiles, por ele ganhas no célebre episódio do Juízo, levadas pelas águas do mar, foram dar na praia, arrastadas até junto à tumba de Ájax. A anedota compõe assim uma memória histórica daquele episódio mítico por velada denúncia contra a injustiça cometida pelos gregos. Mas, tanto mais comprometedora, porquanto advertia que fora apenas graças à intervenção corretora da natureza, a desfazer aquele imperdoável erro humano, que a justiça triunfara.

Platão, em um de seus diálogos (A Apologia de Sócrates, 41b), condensou similar memorização histórica em breve alusão ao mito de Ájax. Dentre outros dos argumentos com que Sócrates se declara disposto a acolher sua passagem para o Hades, ele lembra o ensejo de, nessa nova morada, não só usufruir a companhia de Orfeu, Museu, Hesíodo e Homero, se for verdade que tal seja possível, como ainda deparar-se com mais outros entretenimentos maravilhosos, estes mais estreitamente afeitos à própria história de seu destino: quando viesse ele a encontrar Palamedes, Ájax Telamônio e outros antigos igualmente mortos por sentença iníqua, poderia então comparar seus próprios sofrimentos com os deles.

Píndaro firmou também em seus epinícios denúncias, a acusar a perversidade daquele juízo por que se encerrara o funesto conflito entre os dois heróis. Por essa decisão ajuizante, os antigos, celebrados pelos mitos, haviam preterido a valorosa bonra guerreira do mais forte e bravo, Ájax, nobre coração, primor de esforços bélicos, pela astúcia pérfida de Odisseu, antes exímio nas artes da fala aduladora, companbeira do discurso insidioso, obradora de ardis, peste malfeitora. Pois, os dânaos, por um voto secreto, favoreceram Odisseu, eAjax, privado da armadura dourada, deparou-se com a morte. As razões, entretanto paradoxais, da fama glorificante de um herói, Odisseu, por ato assim tão danoso e iníquo que, justamente finalizando a recompensa do mérito acabava antes por obliterar a virtude agraciando 0 vício, adverte o poeta, haveria que percebê-las tanto, por um lado, na malignidade mesma de cada indivíduo humano - pois, a inveja cola no mérito, ela não conflita com a mediocridade -, inveja individual ainda agravada por outra viciosidade, agora no âmbito da composição coletiva do agir humano - a cegueira passional das massas que as faz perderem a verdade -, quanto, por outro lado, responsabilizar também a potência própria da arte poética pois a voz de belos poemas ressoa sempre, ela é imortal -, e assim o renome de Odisseu ultrapassou seus feitos, graças ao encanto de Homero, pois os mitos e a poesia de sublime vôo deram-lhe não sei qual prestígio. (Píndaro, VII Neméia, 20-31; VIII Neméia, 19-37; IV Ístmica, 51-69)

Também Sófocles (Ájax, 1.135-7), na composição de sua tragédia sobre o herói sala- 
mínio, retratou situações que memorizam suspeitas sobre a melhor lisura do julgamento e sua tortuosa sentença favorável a Odisseu. Assim, na cena em que Teucro alterca com os Atridas, enfrentando suas ordens, que lhe interditavam o sepultamento do irmão, o herói arqueiro chega mesmo a acusar manobras furtivas de Menelau a desencaminhar a votação ajuizante, assim fraudando seu justo resultado. 0 próprio Ájax, na mesma tragédia (Ájax, 445-6), similarmente denuncia, senão a ilegalidade fraudulenta dos procedimentos tribunícios, certamente o opróbrio moral de seu injusto veredito, porque este desonrava, antes do que recompensava, o mérito da excelência heróica superior. Amargamente vitupera ele contra a ingratidão dos comandantes da expedição troiana, os dois Atridas, insultando-os por chefes rapaces de armas, eles que, ao concederem em prol de um velhaco aquelas armas, dele por direito guerreiro, as haviam usurpado, desdenhando seus triunfos.

E, todavia, há, nessas várias instâncias de memorização histórica estigmatizadoras da injustiça do Juízo das Armas porque se vitimara a honra heróica de Ájax, uma intriga que perpassa e compromete o melhor alcance hermenêutico de suas apreciações. Esse sentido, por que todas elas consagram a lembrança do episódio mítico, cristaliza na memória histórica a redutora parcialidade de um olhar indignado contra aquele ajuizamento, justamente porque esse olhar discerne valores e preceitos por diversas formas em consonância com a atualidade das tramas mesmas dos próprios intuitos e significações particulares que ensejam cada uma dessas singulares obras.

Tal parcialidade de olhar é por demais evidente nas apreciações compostas pela tragédia sofocliana. Em seu texto elas conformam, através dos termos virulentos da revolta furiosa de Ájax, uma ótica acusatória certamente contaminada pelos desaforos mais estritamente pessoais de avaliação do fato, enviezada pelos ódios rancorosos de um sujeito que se sente supostamente vítima de alegada injustiça. Ótica que se reitera pela corroboração de sentimentos ajuizantes parciais de outros sujeitos, afins do herói. Assim Teucro, que justamente recorreu a similares diatribes desqualificadoras de uma tal injustiça como réplica argumentativa em meio à discussão querelenta com que se contrapôs à ordem dos Atridas, argüindo então de modo a invalidar o princípio de obediência ao comando político proclamado por Menelau. Pelos (des) entendimentos de Ájax e de Teucro, só se alcança uma compreensão do fato judicante em se vituperando contra as mazelas vergonhosas do exercício da autoridade instituída que o fundamenta e sela.

Já naquelas outras instâncias de memorização da injustiça perpetrada pelo Juízo das Armas, parcialidades análogas, conformes aos intuitos de significação próprios de suas respectivas obras, envolvem a preferência desse singular sentido porque elas lembram o acontecimento mítico, de maneira a exaltar o modo da heroicidade que distinguia nobremente Ájax daqueles logros mais vis personificados por Odisseu. Em Píndaro, além das proposições de princípio mais gerais que orientam seu pensamento poético, observe-se que dois daqueles 
poemas, a VII e a VIII Neméias, celebram nobres de Egina, o primeiro Sógenes, vencedor do pentatlo, o segundo, Dinis, vencedor do estádio. Então, glorificação do vitorioso, atleta e cidade, nos Jogos, bem feliz na eleição alusiva de seus mitos modelares; a justamente exaltarem herói Eácida. ${ }^{1}$ Já na notícia guardada por Pausânias, a melhor fama heróica de Ájax projeta também os reflexos de sua glória pelo país e cidadãos eólios que piedosamente acolhem e preservam seu túmulo. Por sua vez, a Apologia de Platão, nas malhas da ironia socrática com que se relembram as iniqüidades das sentenças de morte denunciadas no âmbito de antiquíssimas histórias míticas, prendem-se também outros malfeitores de histórias bem mais recentes, pretensos juízes a vitimarem, agora com seus votos judicantes, a pessoa do filósofo.

Assim, obras de memorização histórica sedimentadoras de um sentido parcial de avaliação do fato mítico, a entendê-lo consoante às tramas subjetivas de seus individuais ensejos e intuitos de memorização mesma. Mas, também, assim igualmente instâncias de desentendimento do fato mítico, porque sua parcialidade oblitera possíveis sentidos objetivos por ele realizados.

Todavia, a questão ainda se complica porque, se as instâncias de memorização textual que sedimentam a acusação da iniquiidade do veredito comprometem assim, pela parcialidade eletiva do enviezamento de seus olhares, a mais plena apreciação do sentido consumado pelo episódio do Juízo das Armas, nem por isso se afasta ainda uma validade consistente de sua denúncia. Pois, mesmo que os gregos, quer os chefes Atridas, quer a massa votante, não tivessem então descaído sua decisão por qualquer falcatrua menos digna, haviam errảdo ainda injustamente: afinal não era sim Ájax, dentre os heróis combatentes em Tróia, fora Aquiles, o melhor dos aqueus?

Nas representações dispostas pelas narrativas míticas, por inúmeras vezes a memória helênica fixou essa apreciação em cenas com que o poeta glorificava Ájax com tal apanágio honorífico. Assim, nos episódios da Ilíada, em meio aos acirrados combates no plaino de Tróia, tanto companheiros quanto adversários reconheceram e proclamaram Ájax o melhor dos aqueus. Afirmou-o, dentre os gregos, Idomeneu (Ilíada, XIII.321-5), e, dentre os troianos, seu maior adversário, Heitor, que com ele medira forças em duelo memorável (Ilíada, VII.289). E ainda também assim o exaltou a voz do próprio Odisseu, em cenas tramadas agora ou pela Odisséia homérica (Odisséia, XI.550), por ocasião da descida do herói ao Hades no monólogo com que interpelou a sombra do Telamônio, ou pelo Ájax sofocliano (Ájax, 13401), por ocasião do debate acerca das honras do sepultamento do herói suicida.

Declarações de Odisseu a louvar Ájax como o melhor dos aqueus, tanto mais intrigantes quanto formuladas justamente por quem fora, entretanto, em ocasião anterior, no Juízo das Armas, seu rival e ferrenho adversário, a disputar então com Ájax, e a lhe arrebatar o apa-

\footnotetext{
${ }^{1}$ Confiram-se em Heródoto (Histórias, VIII.64 e 121), as tradições com que os gregos assinalavam o prestígio heróico de suas vitórias nas Guerras Medas, fazendo figurar nelas a presença do concurso de seus heróis Eácidas.
} 
nágio de ser honrado justamente por tal distinção mesma com que ganhara a posse das armas de Aquiles. Intriga que os críticos modernos ${ }^{2}$ logo equacionam como prova cabal da injustiça daquele julgamento, pois quem fora favorecido por seu veredito, agora todavia asseverava que o melhor mesmo era o outro, seu adversário entretanto preterido. Portanto, clamoroso erro judicante!

Ilações hermenêuticas da crítica moderna, a meu ver, entretanto, equivocadas ao assim especularem que as proclamações de Odisseu, nos ensejos daquelas duas ocasiões, asseverem o reconhecimento da injustiça do Juízo das Armas, como se estivesse ele então admitindo que quem, por mérito de excelência superior, deveria mesmo ter sido contemplado com aquele prêmio honorífico fosse não ele, mas sim Ájax. É que as proclamações de Odisseu a louvar Ájax como o melhor dos aqueus atualizam-se em tempos e realidades precisas, em ocasiões outras que circunstanciam questões outras que não são propriamente aquelas concernentes aos méritos heróicos enquanto critério de atribuição das armas de Aquiles como prêmio ao melhor dos aqueus. 0 tempo e realidade de apreciação desta questão por avaliação judicante está já encerrado, finalizado. Aquelas proclamações de Odisseu não têm alcance retroativo a negar o fato consumado, elas não implicam questionamento de sua injustiça por veredito equivocado de aferição de excelências heróicas. Quer-me parecer que a disjunção de tempos e realidades conformadas pelas narrativas míticas não comportem razões para uma tal inferência de (con)fusão hermenêutica. Lá, no tempo e realidade do Juízo das Armas, em que a questão se atualiza propriamente, a ação de Odisseu é totalmente outra que a suposta pelas conjecturas da crítica moderna: Odisseu tanto mais entende ser ele o melhor dos aqueus a merecer aquele prêmio, quanto justamente assim o proclama postulando seus reclamos naquela disputa com e contra Ájax. Não nos consta que então tivesse argüido a justiça de sua concessão a favor desse seu adversário!

Mas, há ainda outro registro da memória poética que mais taxativamente proclama a excelência maior de Ájax na Guerra Troiana, pois singularmente a representou como fato mesmo dessa realidade mítica, assim formulada em nome da voz narrativa do próprio aedo, Homero, que no Catálogo das Naus externou expressamente tal juízo, declarando que, depois de Aquiles, o melbor dos aqueus era Ájax Telamônio. (Ilíada, II.768-9) ${ }^{3}$

Então, já em Homero, obra de memorização a associar as figuras heróicas de Ájax e Aquiles, assim as apresentando como marcos supremos de realização de excelência, de areté guerreira, no cerco à cidadela troiana. Projeção paralela de valorações heróicas que a tradição mitográfica pós-homérica conformou em genealogia, aparentando os dois heróis: de Éaco, filho de Zeus, por Endeis, nasceram Peleu e Télamon, e destes, Aquiles e Ájax. ${ }^{4}$

\footnotetext{
2 Confiram-se as indicações dadas por Winnington-Ingram, 1958, p. 58, n. 4; também Fisher (1992, p. 312, n. 92) e Meier (1991, p. 219).

3 Confiram-se também: Iliada, XVII.279-80 e Odisséia, XXIV.17-18. Também Alceu ecoou essa formulação: Da raça do rei Cronida, Ajax, o melhor após Aquiles.
} 
Se então, fora Aquiles, Ájax era mesmo o melhor dos aqueus, por que no Juízo das Armas concederam os gregos tal título honorífico a Odisseu, e não ao Telamônio? Que razões objetivas fundantes da concepção heróica de excelência, areté, poderiam estar assim consagradas pela memória desse episódio? Ou, no vazio dessa falta de objetividade, apenas se pode ter do acontecimento o desentendimento com que aqueles olhares subjetivos o denunciaram como iníqua injustiça, negação de tais princípios fundantes da honra heróica, a estigmatizar para sempre o opróbrio do terrível erro helênico em sua decisão favorável a Odisseu?

Retomemos, pois, do princípio, recompondo o que nos restou das memórias narrativas com que os helenos contaram os episódios constituintes desse fato mítico.

\section{Os JOGOS E AS ARMAS}

A memória homérica desse acontecimento (Odisséia, XXIV. p. 85-97) guardou dele apenas breve notícia, rapidamente sumariada pela alma de Agamêmnon ao encontrar a de Aquiles lá no Hades. A encerrar as honras fúnebres celebrantes do magnífico herói, sua mãe, Tétis, proclamara a abertura dos jogos, depondo no meio da arena esplêndidos prêmios. Jogos e prêmios inigualáveis, consoantes à excelência máxima do herói então glorificado, por demais caro aos deuses. Nesse seu relato, 0 Atrida disse somente do excepcional maravilhamento de quem assistira àqueles jogos.

Já o mitógrafo posterior, Apolodoro (Epitome, V.5-6), registrando-os pela crônica descarnada de uma esquemática narrativa episódica, fixou a lembrança de alguns vencedores: Eumelo na corrida de carros, Diomedes no estádio, Ájax no arremesso do disco e Teucro no disparo do arco.

Então, por fim, o prêmio maior: as armas do próprio Aquiles, de confecção divina, obra primorosa do deus ferreiro, Hefesto. Qual prova melhor decidiria o mérito atribuidor de sua posse? Pelos contornos da memorização mítica desse episódio, confunde-se uma duplicidade de razões. Por um lado, por serem as armas de Aquiles, portavam em si a marca dessa sua origem excepcional a distingui-las como herança de uma singular identidade heróica: certamente deveriam caber, pois, ao melhor dos aqueus. E, por outro lado, implicavam-se na decisão de sua concessão razões de direitos guerreiros, devendo justamente ficar com sua posse o herói que as tomara em combate. Então, qual dos aqueus assim as salvara de cair em mãos inimigas? Quem, em meio à ferrenha luta travada junto às Portas Céias, resgatara o cadáver de Aquiles, impedindo que os troianos o despojassem de suas armas e ainda o aviltassem por múltiplos outros atos desonrosos?

\footnotetext{
${ }^{4}$ Apolodoro, Biblioteca, III.12. Confiram-se as indicações e comentários de Frazer ao texto de Apolodoro (p. 57), bem como as considerações de Fleischer no Léxico de Roscher (s.v. Ájax).
} 
Dois estupendos heróis pleitearam os devidos reclamos por essa honra: Ájax e Odisseu. Mas a qual dos dois, então, melhor cabia o mérito de um tal feito? Quem especialmente defendera o corpo de Aquiles, resgatando-o da confusão dos combates?

A memória homérica desse resgate (Odisséia, XXIV. 36-45) é, de novo, um tanto indefinida em seus informes, compondo apenas alusões. Em uma delas, a alma de Agamêmnon, em relato à de Aquiles no Hades, lembra somente o lutuoso combate ao redor do cadáver, a consumir miríades de heróis de ambos os lados, e a preencher todo o dia, interminável em sua indecisão, até que Zeus o liquidou desencadeando tempestade inviabilizadora de lutas. Assim o herói diz do êxito vitorioso da defesa aquéia do corpo, então transportado para as naus, longe da peleja, a já reclamar honras fúnebres. Quem, pois, pela memorização do olhar do chefe Atrida, salvou o cadáver de Aquiles? Apenas um nós, a comunidade dos companheiros aqueus, é assim referida pelas revelações de Agamêmnon. Contornos de memorização do. acontecimento que, dissolvendo no cometimento comunal de todos quaisquer lembranças que destaquem feitos heróicos individuais, bem condizem com uma ótica própria do comando guerreiro, sobre o qual recaem tanto as loas pelos êxitos da expedição, quanto as censuras pelo fracasso.

Uma outra indicação homérica (Odisséia, V. 299-312) conforma-se pelas aflitivas lembranças de Odisseu. 0 herói vagava em sua jangada por dezoito dias, à vista já das montanhas feácias, quando a perseguição do deus irado, Posídon, o alcançou novamente, desdobrandolhe outro padecimento: a divindade marinha agitou contra o navegante solitário medonha tempestade, de turbulência caótica, composta por todas as espécies de ventos. Então, consciência heróica de um terrivel perigo, receando antever o anúncio cósmico de sua morte inglória, à mente de Odisseu vêm agora a lembrança de outro episódio igualmente assim ameaçador: lá em Tróia, quando inumeráveis troianos disparavam-lhe êneas lanças ao redor do Pelida morto. Alusão que, por certo, apenas memoriza a participação de Odisseu no episódio, não comportando senão inferências elípticas quanto a tudo o mais.

Dois poemas cíclicos especialmente narraram o acontecimento. Segundo a Etiópida, conforme o resumo registrado por Proclo, é Ájax quem se apodera do cadáver subtraindo-o aos inimigos, e o transporta para as naus. Odisseu cobre sua retirada, rechaçando os troianos. ${ }^{5}$ Assim também o afirmava a Pequena Ilíada, pelo que se depreende do escoliasta que a mencionou a glosar uma passagem dos Cavaleiros de Aristófanes. E tradição narrativa similarmente fixada pelo relato do mitógrafo tardio, Apolodoro (Epitome, V.3-4), que diz ter Ájax, após matar Glauco, despojado o cadáver de Aquiles de suas armas, logo as mandando para as naus; já o corpo mesmo, retirou-o da pugna em meio à saraivada de dardos com que o agrediam os troianos. A seu lado, Odisseu os combatia.

${ }^{5}$ Um papiro (Oxirrinco, 2510), em estado bem fragmentário, talvez referente à Etiópida, sugere, porém não cabalmente, uma inversão no retrato das ações heróicas de Ájax e Odisseu: este teria carregado o cadáver aos ombros, enquanto aquele defendia sua retirada. (Fragmentos de Épica Griega Arcaica, p. 147) 
Então, pela abordagem da razão desse feito guerreiro, prova insolúvel, travada pelo impasse de uma indecisão, pois tanto Odisseu quanto Ájax assim salvaram o cadáver de Aquiles com suas armas.

Ora, como Ájax e Odisseu dissentissem então a disputar o primado acerca de suas respectivas excelências, a sapiência experiente de Nestor vislumbrou a via de saída do impasse. No conselho dos helenos propôs que se enviasse dentre eles escutas a surpreenderem, sob as muralhas de Tróia, que juízos trocavam os inimigos a respeito da bravura daqueles dois heróis (Pequena Ilíada, escólio a Aristófanes, Cavaleiros, 1.056). Assim o ancião discernia o modo de alcançar uma decisão imparcial, não distorcida pelas preferências dos vínculos pessoais subjetivos dos ajuizantes helênicos.

E os escutas ouviram uma discussão entre algumas jovens troianas que justamente desdobrava aquele debate. Uma delas discorria a favor de Ájax, bem superior a Odisseu, argumentando que fora aquele herói quem tomara o corpo do Pelida e o retirara da pugna, o que Odisseu, pelo contrário, não se dispusera a fazer. Mas a outra troiana, por premeditação de Atena, não se deixou convencer, antes replicou-lhe que ela estava a proferir coisas absurdas e enganosas. Que impropriedades então falseavam aquele arrrazoado da primeira troiana esclarecem-se por dois versos aristofânicos dos Cavaleiros (1.056-7), os quais foram justamente glosados pelo escoliasta que os referiu à disputa entre Ájax e Odisseu, outrora narrada na Pequena Iliada, e, portanto, supostamente atribuíveis à réplica da segunda troiana:

mesmo uma mulber levaria a carga, se um bomem lha depusesse; mas não combateria, pois desabaria se combatesse.

Assim, na comédia aristofânica, o salsicheiro, na disputa de pronunciamentos oraculares travada com o paflagônio pela obtenção do favorecimento, enquanto seu intendente, de Demos, desqualificava aos olhos deste qualquer mérito daquele, Cléon, que se pavoneava por ter trazido para Atenas aquela carga de prisioneiros, os lacedemônios sitiados em Esfactéria: feito de tanta coragem quanto a de uma mulher, afeita apenas a encargos servis, ente inútil nas lides guerreiras próprias de homens, pois quem de fato conquistara aquela vitória no campo de batalha fora Demóstenes, o comandante que chefiava os atenienses. $\mathrm{E}$ assim também teria argumentado a segunda troiana, a menosprezar as mesmas mazelas femininas do esforço de Ájax diante da viril virtude guerreira de Odisseu ao salvar o corpo de Aquiles.

Outra história (Odisséia, XI.547), similar a essa, também aludia à intervenção do parecer dos troianos encaminhando decisão favorável a Odisseu. Ao narrar o encontro deste herói com a sombra de Ájax no Hades, Homero menciona a vitória do primeiro no Juízo das Armas de Aquiles, postas à disputa entre os aqueus como prêmio pela mãe venerável, Tétis. E afirma que assim o ajuizaram os filhos dos troianos e Palas Atena. Ao que o escoliasta aduzia a história explicativa. Fora Agamêmnon quem, para se livrar dos dissabores suscitados por aquele 
espinhoso julgamento, remetera a decisão a um tribunal especialmente composto por prisioneiros troianos, deles inquirindo qual daqueles dois heróis causara mais danos aos inimigos. E estes apontaram Odisseu.

Assim, ajuizando a efetividade ruinosa da obra guerreira contra Tróia, decidiu-se pela eleição de Odisseu a disputa heróica pela posse das armas de Aquiles. Firmava-se agora que Odisseu era assim o melhor dos aqueus.

\section{ARETÉ}

Mas o que, no plano das representações e conceituações míticas do modo heróico de existência humana, se entende pela qualificação de ser o melbor?

Entre a existência humana e o ser divino, o estatuto da condição heróica situa um modo ambíguo de ser, tão bem divino quão humano: humano porque estigmatizado pelo fato da mortalidade, e divino porque distinguido especialmente por honras privilegiadoras de grandeza excepcional. Heróis são os áristoi, categoria diferenciada de guerreiros avançados, os prómakhoi, que combatem à dianteira, assim distinguidos e mesmo dissociados da massa dos meros combatentes anônimos, que compõem exército apenas pela realidade coletiva do número. Qualificações de melhor e primeiro definem a excepcionalidade da excelência, da areté, de sua dignidade guerreira.

E o poeta, Homero, diz a areté distinguidora de cada nome heróico, identificando dupla instância de determinação, por um lado circunstancial, por outro atributiva. Ser o melhor supõe a circunstância de uma dada e certa comunidade, um círculo demarcado de associação humana em que um indivíduo, bem nomeado, se distingue como o melhor de todos eles. E ser o melhor supõe também a especificação de um dado e certo atributo ou qualidade por cuja prática aquele indivíduo singular se distingue e prova ser superior. Assim, no país dos lícios, não havia melhor arqueiro do que Pândaro (Ilíada, V.171-3). Em sua comunidade, Mérope mais do que ninguém conhecia a arte profética (Ilíada, II.831-2). Já na sua, era Euridamante quem primava no domínio de tal competência de hermenêutica onírica (Ilíada, V.149). Como caçador, em sua terra, Escamândrio a todos superava, perito mateiro (Ilíada, V.49-54). Por artífice, o melhor de todos era Féreclo (Ilíada, V.60). Como coureiro, o mais exímio era Tíquio, quem justamente confeccionou o escudo-torre de Ájax (Ilíada, VII.220-1). Na comunidade dos feácios, excelente aedo era Demódoco, e já em Ítaca, Fêmio, que como ninguém conhecia os cantos das gestas de heróis.

Similarmente se concebem as precípuas excelências que distinguem individualmente cada herói congregado por essa singular comunidade dos guerreiros helênicos expedicionários contra Tróia. Por prudência sapiente de conselhos e deliberações, bem condizente com 
veneranda velhice, excelem os préstimos de Nestor (Odisséia, III.243-5; Ilíada, I.247-9). Por arte de arremeso do dardo, contavam os gregos com a perícia de Ájax Oileu, primoroso lanceiro, e ainda velocista formidável. Destreza no manejo do arco destacava a figura de Têucro, sem que acarretasse prejuízo de valor guerreiro para o combate de perto (Ilíada, XIII.313-4). Em dignidade régia, rei maior em poderio, firmava Agamêmnon sua areté (Ilíada, I.277281). Na ciência da disposição e arranjo dos carros de guerra ordenados em formação de combate, sobressaía-se o ateniense Menesteu, com quem só Nestor rivalizava (Ilíada, II.553555). Por manhas e recursos astuciosos, Odisseu não tinha igual (Iliada, III.200-202; Odisséia, XIII.291-301). E guerreiro maior, por força, bravura, coragem, velocidade e demais qualidades de virilidade bélica, Aquiles.

Mas também Ájax Telamônio lá estava, nos plainos troianos, enquanto guerreiro campeão. Então, que âmbito mais precípuo de realização de heroicidade bélica especialmente assinala a areté de Ájax?

\section{A TORRE}

Do alto dos muros de Tróia, Príamo interroga Helena acerca da identidade dos campeões aqueus. Bem reparara num deles, de nobre porte, cuja figura enorme se destacava proeminente entre todos os argivos, tanto pela altura quanto pelos largos ombros. Esse, respondeu a heroína, é Ájax, um colosso, baluarte dos aqueus. (Ilíada, III.226-9)

Figura gigantesca excepcional, Ájax tem consoante armamento distintivo: o escudo. Terrível arma de defesa, robusta, densa por sete camadas de couro taurino revestidas por oitava brônzea faiscante, obra monumental de lavor primoroso confeccionada por exímio artesão coureiro - Tíquio -, que resiste incólume, apenas reboando, ao portentoso tiro de ingente pedra negra desferido por Heitor (Ilíada, VII.219-24; 263-7). Sua forma é especialmente singular: semelho a uma torre, ou bastião de uma muralha (Iliada, VII.219). Sob sua proteção se refugia Teucro, hábil arqueiro, quando em combate se associa ao irmão: espiona os adversários aproveitando os deslocamentos com que o move Ájax, e rápido alveja um, logo se recolhendo àquele abrigo como criança que afunda no regaço materno.$^{6}$ Arma rara, inusitada, relíquia da memória poética. ${ }^{7}$

\footnotetext{
${ }^{6}$ Iliada, VIII.266-72. Prudente modo de combate de um arqueiro, pois quando Teucro, animado pelo rol de adversários assim mortalmente feridos, delongou-se fora da proteção do escudo, falhando já por duas vezes em alvejar cobiçado inimigo, Heitor mesmo, e insistiu em um terceiro disparo, o adversário acertou-o primeiro com portentosa pedrada, baqueando-o por terra desarmado. Então, presa inerte do cão raivoso, ainda o salvou o irmão, resguardando-o pela proteção de seu escudo brandido ao redor. (Ilíada, XI.330-1)

70 escudo-torre, retangular alongado a cobrir as pernas também joelho abaixo, é apenas atestado arqueologicamente por representações figuradas datáveis do século XVI a.C. (Courbin, Problèmes de la Guerre, p. 95)
} 
Pelo escudo bem se distingue e identifica Ájax. ${ }^{8}$ Então, pýrgos - torre, bastião - denomina tanto o escudo, quanto o guerreiro que o porta. ${ }^{9}$ Assim, pois, Homero diz do armamento e da idiossincrasia de Ájax.

Firmeza de manutenção de posicionamento e solidez de resistência guerreira que defronta e barra, inabalável, tenaz, jamais cediço ou fatigado, os avanços inimigos. Quando Idomeneu pondera junto a Meríones o ponto onde deveriam ambos adentrar o combate, que mais necessitado fosse de defesa face à furiosa arremetida troiana contra as naus aquéias, logo descarta aquele em que depara Ájax. 0 rei cretense aprecia então a excelência guerreira que o distingue. (Ilíada, XIII.321-5)

\section{o grande Ajax Telamônio não recuaria diante de um bomem que mortal fosse, que of fruto de Deméter comesse, e que pelo bronze ou por enormes pedras vulnerável fosse. Nem mesmo a Aquiles rompedor cederia no corpo-a-corpo; mas este, pela corrida, jamais teria rival.}

Não há poder guerreiro, desde que humano, que mova Ájax a ceder sua defesa: não o conseguiria nem mesmo o maior herói, excelência suprema de potência guerreira ofensiva, a abalar e fazer recuar defesas inimigas, Aquiles. Recuo de Ájax, a retroceder sua defesa guerreira, só é admissivel se concebido através de expressa deçisão divina.

$\mathrm{E}$ é assim que Zeus o detém, infunde-lhe temor, e o obriga à retirada dando realização ao avanço troiano que acossa os aqueus junto às naus. Então Ájax retrocede, escudo lançado às costas, mas só bem vagarosamente, compassando volteios de furor apavorante com que contém seus perseguidores. Acata o retrocesso imperioso e, todavia, não é a saraivada de golpes com que 0 atingem que $o$ força, a eles obstinadamente indiferente. Pelo contrário, é ele quem comanda os movimentos, que determina quando e quanto permite de avanço inimigo. Eis como, retrata Homero (Ilíada, XIII.569), Ájax recuava e, assim o fazendo, justamente $a$ todos impedia de se encaminharem para as céleres naus. Ambígua concepção poética do retrocesso de um baluarte guerreiro que jamais, mesmo então, quando recua, perde sua precípua potência de barragem.

Ájax, pois, bem compõe paralelo heróico com Aquiles, marcando realizações extremas de excelência de potência guerreira no cerco de Tróia. Assim o figurou o aedo (Ilíada, VIII.2246), ao expor qual era a disposição das tendas dos heróis que alinhavam 0 acampamento aqueu: diz que eles ambos, em sua coragem confiantes e na força de seus braços, puxa-

\footnotetext{
${ }^{8}$ Cebríones, combatendo como cocheiro ao lado de Heitor, adverte-o da carga furiosa do avanço aqueu, logo apontando o guerreiro assassino que o comanda: é Ajax Telamônio, bem o reconbeço, pois largo em torno dos ombros tem o escudo. (Ilíada, XI.526-7)

9 Odisseu precisamente assim qualifica a figura de Ájax: ele é a torre dos aqueus. (Odisséia, XI.556)
} 
ram suas naus para os extremos. Postando-se como baluartes terminais da formação aquéia, cada um por si mesmo defendendo aquelas posições singularmente diferenciadas por destacado perigo guerreiro, os dois heróis proclamavam a primazia de suas excelências em afirmando a autonomia da bravura precípua com que as fundam. Mas, simetria especular de excelência guerreira suprema por distintos princípios de eficácia beligerante: com Aquiles, furor de agressão ofensiva, com Ájax, baluarte de resistência defensiva. Suas armas distintivas simbolicamente os assinalam: a lança para Aquiles, o escudo para Ájax. (Méautis, 1957, p. 14-15)

\section{A EXPEDIÇÃo TROIANA}

Então, a plêiade de heróis que compõe o corpo expedicionário grego a Tróia configura mosaico completo de diversos recursos de competências beligerantes, todos configurados ao nível de excelência heróica, cuja composição e soma é devidamente requerida e apropriada para o melhor êxito da campanha bélica. Cada areté assim reclamada destaca no empreendimento beligerante conjunto a presença e efetividade de uma precípua figura heróica, bem nomeada por consoante fama. Cada e todo herói, participante do esforço bélico contra Tróia, afirma justa excelência como condição de sua presença e, pois, como princípio guerreiro do êxito aqueu e causa da ruína de Tróia.

Plêiade de heróis, diz o mito, desde o princípio destinada para a guerra troiana, pois originariamente congregada como rol de pretendentes a disputarem a mão de Helena, tendo juramentado a obrigação de seu singular empenho guerreiro na defesa da união conjugal então consumada. Todos os heróis, menos um, Aquiles, naquela ocasião, diz o mito, ainda muito jovem para postular reclamos nupciais. Mas, assim que os aqueus decidiram mover guerra contra Tróia, Calcas, sábio profeta, bem os advertiu: que fossem em busca também de Aquiles, pois, sem seu concurso guerreiro, a fortaleza jamais seria tomada. (Apolodoro, Biblioteca, III.10; Hesíodo, Catálogos 68)

Então, assim completos, congregaram-se os heróis aqueus pelo empreendimento guerreiro contra Tróia.

A chefiar inúmeras incursões fulminantes, Aquiles arrasa o país troiano, saqueia e pilha por todos os lados, multiplicando-se os nomes das cidades vencidas em terra e por mar, e acumulando-se os bens e valores tomados como despojos. 0 próprio herói, na cena da embaixada em que argumenta denunciando a ingratidão de Agamêmnon no comando régio da expedição, realça o alcance devastador de sua potência guerreira (Ilíada, IX.328-9):

Doze cidades dos bomens com minhas naus devastei, e por terra afirmo que foram onze, na fértil Tróade. 
De muitas incursões memorizou-se apenas o nome da cidade arruinada, cujo registro meramente acrescia marcas à fama de Aquiles, eversor de cidades. Assim Lesbos, Focéia, Cólofon, Esmirna, Clazômenas, Cime, Egíalo, Tenos, As Cem Cidades, Adramiteo, Side, Êndion, Colone, Tebas Hipoplácia, Lirnesso, Antandro, e ainda várias outras de que, entretanto, a memória helênica não guardou o nome. (Apolodoro, Epitome, III.33)

E, também os príncipes troianos, filhos de Príamo, tombaram pelas mãos de Aquiles. Assim, Troilo, de quem se diz que só nominalmente era seu filho, pois Hécuba o gerara de Apolo. Uma profecia prognosticava a invencibilidade de Tróia, caso esse príncipe chegasse aos vinte anos de idade. Mas Aquiles desfez as esperanças troianas, cortando-lhe antes o fio da vida. ${ }^{10}$

E eram já decorridos dez anos de guerra incessante, plenos de devastações e mortes, sem que, nem assim, caísse a cidadela. Pois, o troiano, filho de Príamo, que primava por sua defesa era um não menos formidável herói, Heitor, de elmo flamejante, obstáculo inexpugnável a frustrar as pretensões aquéias. ${ }^{11}$

Mas as tramas dos desígnios divinos enredaram em um episódio os destinos dos dois magníficos heróis, antagônicos diante de Tróia, Heitor a defendê-la, e Aquiles a investi-la. Esse episódio, principiado apenas como mais uma das inúmeras partilhas de despojos troianos, mas que agora envolvia a honra do poder apolíneo através da figura de seu venerando sacerdote, Crises, então aviltado por Agamêmnon, desdobrou-se pela ira de Aquiles, desonrado pelo Atrida que o privara de seu justo prêmio de guerra.

\section{O RETTRO de AquiLes}

Aquiles, alheio aos combates, isolado em sua tenda, em cisão contra os aqueus: paradoxal desenlace da opção de um destino guerreiro. Pois, após longos dez anos de extenuantes esforços belicosos, acumulando feitos e mais feitos a afirmar sua excelência heróica, obtinha Aquiles, como resultado desse primor de viver guerreiro, a desonra! 0 episódio, portanto, frustra a opção heróica de Aquiles, já que os esforços e riscos guerreiros valem pela contrapartida de honras que eles finalizam. Ora, Aquiles cumpre os trabalhos da guerra, mas deles não lhe advêm honras, pelo contrário, é delas privado. É essa negação do sentido próprio de seu singular destino, que ele, queixoso, lamenta perante sua mãe, Tétis (Iliada, I.352-6):

\footnotetext{
${ }^{10}$ Confiram-se as indicações dadas por Frazer em suas notas ao texto de Apolodoro, v. 2, p. 202.

11 Estrabão (Geografia, XIII.1.27, 594C) conta uma anedota: quando Fímbria, o questor romano destacado para as operações na Ásia Menor por ocasião da I Guerra Mitridática, tomou de assalto, após um cerco de dez dias, a cidade de llium, pôs-se exultante a gabar-se de seu feito, proclamando que o que Agamêmnon, provido de milhares de navios mais toda a Grécia, levara dez anos para consumar com muita dificuldade, ele realizara em apenas dez dias. Mas um dos habitantes da cidade logo replicou: "Sim, pois o campeão da cidade não era Heitor".
} 
Mãe, já que me geraste, todavia para breve existência, bonra, porém, a mim devia conceder o Olímpio, Zeus trovejante. Mas, agora não me bonra nem um pouco, pois o Atrida Agamêmnon, poderoso senhor, me desonrou: tomou e detém minha recompensa, que ele mesmo tirou.

Na prece que dirige à mãe, Aquiles, lamentando os dissabores de seu destino guerreiro, queixa-se, não diretamente contra Agamêmnon, que o desonrara expropriando-o de seu prêmio honorífico, mas, sim, contra Zeus, dado como o princípio de determinação responsável pelo devido cumprimento desse destino enquanto plenificação de honras.

0 rogo de Aquiles fora, assim, muito bem endereçado. Pois não só reclamava distinções honoríficas da devida instância de poder divino a quem justamente competiam os favores de sua concessão, Zeus Olímpio, quanto, ainda, intermediava seu pedido através da pessoa de Tétis, a quem favores passados, prestados ao tempo em que Zeus firmava seu poder soberano, obrigavam 0 beneplácito do rei dos deuses.

Assim formulado por Tétis e anuído por Zeus, viabilizou-se o modo pelo qual se realizaria o destino honorífico da existência guerreira de Aquiles. Ele, que só dissabores e desgostos colhia de seus empenhos guerreiros, retirava-se dos combates, inativo em sua tenda. Dada esta sua ausência guerreira, aguardava-se o êxito troiano a acrescer vitórias sobre vitórias, em avanço irresistivel contra as naus aquéias. Os gregos, então, assim terrivelmente acossados pela derrota, a acumular-lhes mortes sobre mortes, ver-se-iam obrigados a admitir sua dependência para com a força guerreira de Aquiles, cujo retorno à atividade exigiria, agora, a plena satisfação de sua finalidade honorífica, a cumulá-lo de bens e distinções.

Então, a efetivação do sentido honorífico do destino guerreiro, por que optara o viver de Aquiles, conformava, agora por sua ausência da guerra, a mais profunda contradição: paradoxalmente, a honra do herói advém não quando e porque ele guerreia, mas, sim, quando e porque se afasta dos combates, evita a guerra.

E a decisão de Zeus, atendendo à súplica de Tétis, se realiza. A ausência de Aquiles enseja a reversão do sentido por que, até então, se direcionavam os esforços do confronto guerreiro: pela falta de Aquiles, cessa a agressão do cerco aqueu que acuava os troianos na cidadela, dando lugar ao avanço da defesa troiana, agora já configurada como ofensiva que rechaça mesmo os gregos contra suas naus acampadas na orla praiana, a ponto de ameaçar incendiálas. ${ }^{12}$ Assim, os troianos avançam decididos, imbatíveis em sua investida, comandados e insuflados por Heitor, e os gregos, embora denodadamente heróicos, recuam, retrocedem no campo de batalha, e são empurrados contra as naus.

Tempo de guerra em que, agora, os gregos estão compelidos à defensiva. E os gregos,

12 Iliada, v.787-791. Vejam-se os comentários de Edwards, 1987, p. 86. 
agora, atualizam uma diversa comunidade guerreira associada diante de Tróia: sem o concurso da ação de Aquiles, entretanto inativo em sua tenda. Já os troianos, Heitor bem os comanda, insuflando furioso o ataque. Então, pelo interregno desse tempo que a ira de Aquiles demarca, bem se realiza o primado do princípio heróico precípuo da areté de Ájax, baluarte gigantesco e jamais cediço de resistência defensiva, verdadeira torre a conter e deter as agressões comandadas por Heitor. E assim Ájax bem se distingue e prima, dentre os aqueus todos, por enfrentar Heitor: duela gloriosamente com o campeão troiano e, depois, mais do que todos defende as naus aquéias do iminente incêndio com que as ameaça o herói troiano. Pelo tempo da ausência de Aquiles, Ájax é, certamente, dada a atualização desse justo sentido defensivo do empenho guerreiro helênico, o melhor dos aqueus.

$\mathrm{E}$ assim claramente o consignou o poeta, ao catalogar a comunidade aquéia congregada no cerco, inquirindo a Musa a declarar-lhe justamente essa questão (Ilíada, II.763-79):

As éguas de longe melhores eram as Ferecíadas,

que Eumelo dirigia, velozes como pássaros,

de mesmo pêlo, mesma idade e com dorsos nivelados.

Elas que, na Piéria, Apolo do arco argênteo criou, ambas fềmeas, portadoras do terror de Ares.

Dentre os guerreiros, de longe melbor eraÁjax Telamônio, enquanto Aquiles esteve irado; pois ele era bem superior, e também seus cavalos, condutores do irrepreensivel Pelida. Mas, ele nos navios recurvos, cruza-mares, quedava, rancoroso contra Agamêmnon, pastor de povos, o Atrida; e os guerreiros junto ao quebrante das ondas divertiam-se com discos e com dardos a disparar, mais setas; $\boldsymbol{e}$ os cavalos, cada um junto a seus carros, a pastar o lótus e a salsa dos pântanos ficavam; $\boldsymbol{e}$ os carros, bem recobertos, permaneciam nas régias tendas; e eles, pelo comandante caro a Ares pesarosos erravam pra cá e pra lá, através do acampamento sem combater.

A Musa, assim interpelada pelo aedo a declarar-lhe quem era, dentre os heróis aqueus sitiantes de Tróia, o melhor, distingue dois tempos. Uma ação demarca essa dissociação temporal: Aquiles em ira contra Agamêmnon. Aquiles irado, rancoroso contra Agamêmnon, insubordinado à chefia da expedição, situa precípua inação guerreira. Retirado dos combates, quedava sua potência bélica inerte no acampamento. Ao seu redor, polarizado solidariamente pela resolução régia soberana, o espaço demarcado pela comunidade dos Mirmídones é similarmente contaminado por esse efeito de anulação guerreira. Dos guerreiros, uns/ora, mais despreocupados, entretêm-se compondo os prazeres atléticos próprios da dignidade heróica do lazer guerreiro; já outros/ora, tomados de pesar, vagueiam errantes por esse espaço, traçando percursos inúteis, cuja única ação consiste em dissipar o tempo beligerante. Idêntico 
destino de inação guerreira alcança seus precípuos recursos e agentes de mobilidade bélica, condutores do irrepreensível Pelida: carros recolhidos, abrigados por cobertas protetoras; e cavalos que apenas pastam, prolongando contínuo o tempo que, entretanto, assim teria sentido só momentâneo, a alternar ações beligerantes enquanto revigoramento.

Portanto, na atualidade desse tempo da ira de Aquiles, o melbor dos aqueus é Ájax Telamônio, pois então anula-se, nega-se a areté de Aquiles. Se não, o melhor dos aqueus é Aquiles, pois bem superior era.

\section{Odisseu}

Mas então, Pátroclo, o brioso companheiro de Aquiles, não mais resistiu à aflição angustiante de permanecer assim inativo, excluído das realizações guerreiras, especialmente quando sua atuação era mais reclamada. Rogou ao caro amigo que o liberasse para a luta. Aquiles, embora apreensivo, autorizou-o a retornar ao campo de batalha, e até mesmo the cedeu, emprestada, sua própria armadura. E a investida beligerante de Pátroclo foi brilhante, devastadora, a rechaçar o ataque troiano e, inclusive, a reverter a sorte da batalha. Mas, foi também o fim de Pátroclo, que então tombou morto aos golpes de Heitor, com quem se conluiara o poder de Apolo.

A ira de Aquiles, assim, paradoxal e tragicamente, finaliza com a morte de Pátroclo. Agora o herói, furioso contra Heitor, assassino do querido amigo, encerra o rancor contra Agamêmnon, termina o tempo da ira, e retorna aos combates. É o fim de Heitor. Mas, o fim de Heitor é também o princípio do fim de Aquiles.

Ora, morto o Pelida, novo tempo principia, atualizando diversa comunidade aquéia sitiante de Tróia: agora irremediavelmente privada de Aquiles. Ação beligerante de cerco a uma cidadela agora também diversamente solicitada em seu empenho: não há mais Heitor a combater, o guardião magnífico que obstava o empreendimento de sua tomada, afastando das muralhas as pretensões de investidas invasoras. Pois, agora, o princípio de areté firmado por Aquiles já o removera.

$\mathrm{Na}$ atualidade bélica reclamada por este outro tempo, consubstanciado por essa precisa ação beligerante de invasão e tomada da fortaleza, quem é, agora, o melbor dos aqueus? Ájax e Odisseu postam pretensões a tal honra heróica. Mas Ájax é areté guerreira de potência mais precipuamente defensiva, bem apropriada para eficaz resistência contra avanços de forças inimigas, cujo empenho, entretanto, não é mais agora decisivamente reclamado.

Ora, o que é agora então precipuamente reclamado como efetividade guerreira - penetrar na cidadela, assim ultrapassando o obstáculo de tremendas muralhas intransponíveis -, requer recursos de excelência bélica que nem força, nem coragem, nem bravura ou quaisquer outros modos de mera virilidade guerreira suficiente e apropriadamente contemplam: 
mesmo o herói que, entretanto, era por essas virtudes supremo de excelência, Aquiles, não consumou tal feito militar, ainda que realizando desempenho guerreiro irrepreensivel diante de Tróia. Após dez anos de extenuantes empenhos de sua, entretanto, terrivel potência guerreira agressiva, permaneciam incólumes as muralhas, inviolado o interior citadino troiano. Onde nível de força descomunal é reclamado do herói, inalcançável mesmo para sua grandeza heróica, fica inviabilizada a força mesma como recurso de sua superação. Assim, adentrar a cidadela supõe tramas especiais, pois, para superar 0 adversário há que, paradoxalmente, contar com a própria cumplicidade da vítima a viabilizar sua derrota. ${ }^{13} 0$ feito heróico exitoso supõe agora outra via, a dos logros e ludibrios: a ação da inteligência astuciosa, a obra de métis. $^{14}$

Ao eleger Odisseu, agora, o melhor dos aqueus, em ajuizando a precípua efetividade ruinosa de seu princípio de excelência heróica para o destino do cerco de Tróia, os gregos reconheceram e consagraram a realidade desse fato da história da guerra na Antigüidade, que destaca também a métis, a astúcia, como arte igualmente apropriada, ao lado das potências mais estritamente beligerantes de agressão e defesa, para o êxito último de sua singular finalidade ruinosa. Pela simbologia emblematizada nas excelências heróicas de Aquiles, Ájax e Odisseu, a memória mítica helênica condensa a consciência histórica que conceptualiza as realidades de seus distintos modos de prática guerreira. Assim, ao tempo heróico do primado de Aquiles, apenas cindido pelo interregno do tempo heróico do primado de Ájax, sucede o tempo heróico do primado de Odisseu. É o tempo da efetividade astuciosa decisiva, emblematicamente atualizada pela métis do Cavalo de Pau. É o princípio último do fim de Tróia. Ao contemplarem Odisseu, figura de realização heróica desse princípio, digno sucedâneo de Aquiles, com o apanágio honorífico de o melbor dos aqueus, os gregos obravam justo reconhecimento, tanto mais objetivo e imparcial quanto espelhava a realidade mesma dos fatos de sua história, nem só grega, como ainda do mundo antigo em geral.

PIRES, F. M. Heroic arete and the Trojan War: the best Achean (Achilles, Ajax and Odisseus). Classica, São Paulo, v. 9/10, n. 9/10, p. 143-162, 1996/1997.

${ }^{13}$ Este mesmo modo de trama astuciosa está suposto no Ájax sofocleano, na cena em que o herói, ludibriado pela métis de Atena, acaba por confessar seus atos criminosos contra os aqueus, assim fornecendo a Odisseu as provas que $o$ incriminam decisivamente. Vejam-se nossos comentários no texto Ajax, Atena e os (des)caminbos da métis (cf. Pires, 1994/5).

${ }^{14}$ Confiram-se os preceitos com que Nestor ensina seu filho, Antiloco, a alcançar a vitória quando em situação de inferioridade de bie (lliada, XXIII.304-348). Na Odisséia, as aventuras do herói reiteradamente afirmam esse princípio heróico, exemplarmente assinalado pelo episódio de seu defrontamento com Polifemo. 


\begin{abstract}
7 The article offers a reconsideration of the (in) justice concerning the award of Achil-

le's arms to Odysseus as the best of the Achaeans through an appreciation of the homeric concept of areté.
\end{abstract}

Key-words: Areté; Homer; Ájax; Achilles; Odysseus.

\title{
Referências bibliográficas
}

APOLLODORUS. The Library. With an english translation by Sir J.G. Frazer. London/Cambridge: William Heinemann-Harvard University Press, 1954 [1921].

ARISTOPHANE. Les Cavaliers. Texte établi par V. Coulon et traduit par H. van Daele. Paris: Les Belles Lettres, 1954.

BERNABE PAJARES, A. Fragmentos de Épica Griega Arcaica. Madrid: Gredos, 1979.

EDWARDS, M.W. Homer, Poet of the Iliad. Baltimore and London: John Hopkins, 1987.

FISHER, N. R. E. Hybris. Warminster: Aris and Phillips, 1992.

HESIOD. Hesiod, the Homeric Hymns and Homerica. With an english translation by H. G. EvelynWhite. London/Cambridge: William Heinemann/Harvard University Press, 1967 [1914].

HOMER. The Iliad. With an english translation by A.T. Murray. London/Cambridge: William Heinemann/Harvard University Press, 1971 [1924].

HOMER. The Odissey. With an english translation by A.T. Murray. Cambridge/London, Harvard University Press: William Heinemann, 1938 [1919].

KIRK, G.S. The Iliad: a Commentary, v. 1, Cambridge: Cambridge University Press, 1985.

LYRA GRAECA. v. I. Newly edited and translated by J.M. Edmonds. Cambridge/London: Harvard University Press/William Heinemann, 1934 (1922).

MÉAUTIS, G. Sophocle. Essai sur le Héros Tragique. Paris: Albin Michel, 1957.

MEIER, Ch. De la Tragédie Grecque comme Art Politique. Tradução francesa de M. Carlier. Paris: Les Belles Lettres, 1991.

NAGY, G. The Best of the Achaeans. Baltimore: John Hopkins, 1986.

PAUSANIAS. Description de la Grèce. Livre I, texte établi par M. Casewitz, traduit par J. Pouilloux et commenté par F. Chamoux. Paris: Les Belles Lettres, 1992.

PIRES, F. M. Ájax, Atena e os (des)caminhos da métis. Classica, 7/8 (1994/5): p. 195-209.

PLATÃo. Diálogos. Seleção, introdução e tradução de J. Bruna. São Paulo: Cultrix, 1957.

SOPHOCLE. Ajax. Tome I, texte établi et traduit par P. Masqueray. Paris: Les Belles Lettres, 1922.

VERNANT, J. P. Problèmes de la Guerre en Grèce Ancienne. Paris/La Haye: Mouton, 1968.

WINNINGTON-INGRAM, R. P. Sophocles. An Interpretation. Cambridge: Cambridge University Press, 1980. 